\title{
An Introduction to the Academic Draft Common Frame of Reference
}

\author{
Eric Clive
}

Published online: 14 August 2008

(C) ERA 2008

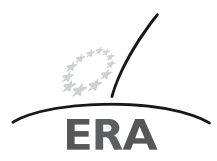

EUROPÄISCHE RECHTSAKADEMIE ACADEMY OF EUROPEAN LAW ACADEMIE DE DROIT EUROPEEN ACADERE DE DROT UROPEN TRIER - TREVES - TREVIRI

\section{Introduction}

First of all, I would like to congratulate the Presidency on the Council's statement of position of 18 April giving the green light to the idea of a Common Frame of Reference as a better lawmaking tool in the area of contract law. ${ }^{1}$ This decision and the Parliament's resolution of December last year ${ }^{2}$ are immensely encouraging to those who have been working in this area - and they are no less so for being cautious and realistic and leaving open some room for manoeuvre.

I have been asked to introduce the Academic Draft Common Frame of Reference. I am very glad to do so.

Its full name is Principles, Definitions and Model Rules of European Private Law: Draft Common Frame of Reference but it can be called the DCFR for short. It is four

Professor Eric Clive $(\square)$

School of Law, Edinburgh University

Old College, South Bridge, Edinburgh EH8 9YL, United Kingdom

e-mail: eric.clive@ed.ac.uk

Visiting Professor, School of Law, Edinburgh University, member of the co-ordinating committee of the Study Group on a European Civil Code and joint chair of the Compilation and Redaction Team for the DCFR. This is a slightly revised version of a talk given at a conference on The Draft Common Frame of Reference, organised by ERA in cooperation with the Ministry of Justice of the Republic of Slovenia in the framework of the Slovenian Presidency of the Council of the EU, held in Ljubljana on 28-29 April 2008.

\footnotetext{
1) On the 18 of April 2008 the Council endorsed a report defining its position on four fundamental aspects of the Common Frame of Reference. Its purpose would be a tool for better lawmaking targeted at Community lawmakers. Its content would be a set of definitions, general principles and model rules in the area of contract law to be derived from a variety of sources. Its scope would be general contract law, including consumer contract law. And its legal effect would be a set of non-binding guidelines to be used by the lawmakers at Community level on a voluntary basis as a common source of inspiration or reference in the lawmaking process

2) The Parliament's Resolution of 12 December 2007 referred to its long history of support for action in this area. It continued to strongly support the idea of a CFR on general contract-law issues and wanted options for its purpose and legal form, including that of an optional instrument, to be kept open.
} 
months old, ${ }^{3}$ gender neutral and without any national allegiance. It is secular but imbued with strong moral principles. It is to a large extent a cross between the Principles of European Contract $\mathrm{Law}^{4}$ and the Acquis Communitaire but it has many other elements in its ancestry. One of its grandparents is the Convention on International Sale of Goods. A close cousin is the Unidroit Principles of International Commercial Contracts. It is currently monolingual, but is expected to pick up other languages very quickly.

\section{Background}

The background to the DCFR has been explained at earlier conferences and will be familiar to most people here. I would just like to emphasise three points.

First, the scale of the project. The DCFR is the fruit of an enormous co-operative European effort which is unprecedented in the area of private law and which could not easily be repeated.

Secondly, the academic DCFR is not the same as whatever official CFR may emerge out of it. It covers a wider field than contract law and it has purposes other than acting as a set of tools for EU legislators. In particular it is to be hoped that it will be useful for contracting parties, ${ }^{5}$ for courts (at all levels up to and including the ECJ) and national legislators and that, once translated into all the official languages, it will provide a common text for academic teaching, analysis and discussion throughout Europe. It is already being used for academic purposes. Courses and seminars are taking place and being organised. Articles are being written. It is also to be hoped that the possibility of using the DCFR as the basis for an optional instrument will be kept firmly open.

Thirdly, the link between the academic DCFR and whatever official CFR may emerge is most important. The academic text has been framed with complete academic freedom but with the Commission's formal requirements in mind. It tries to provide, as requested by the Commission, ${ }^{6}$

"clear definitions of legal terms, fundamental principles and coherent model rules of contract law, drawing on the EC acquis and on best solutions found in Member States' legal orders."

It tries to take fully into account the Commission's further views on definitions, coordination and coherence. ${ }^{7}$

\footnotetext{
3) Having been delivered to the European Commission on 28 December 2007.

4) PECL from now on.

5) Parties might wish, particularly when seeking neutral ground, to incorporate some of the DCFR's provisions into their contracts or to use some terms and concepts derived from the DCFR and provide that they are to be interpreted in accordance with the DCFR.

6) Communication from the Commission on "European contract law and the revision of the acquis: the way forward" (COM (2004) 651 final).

7) See the Commission's First Annual Progress Report on European Contract Law and the Acquis Review (2005). See also the Commission's Second Progress Report on the Common Frame of Reference (COM (2007) 447 final).
} 
"Definitions of abstract legal terms are indispensable for the CFR preparation and need to be included in the drafts ... . Definitions have to be clearly coordinated with the elaborated rules."

"The overall coherence of a draft CFR is crucial. The interdependence between general and specific contract law needs to be clarified. For horizontal issues, coherent solutions need to be achieved."

It is very much to be hoped that the official CFR and the Principles, Definitions and Model Rules of European Private $\mathrm{Law}^{8}$ (or the relevant parts thereof) will remain close to each other in terminology, style and content. This would be to the advantage of both. The academic text will gain credibility by being associated with an official text, even if the latter has a more limited content and a strictly limited purpose. This could increase the usefulness of the whole academic text for contracting parties, national law reformers, legislators, courts and academics and could be particularly important in relation to its potential impact outside Europe. The official CFR will derive benefit over the years from widespread academic analysis and discussion of the whole academic book. It might even be asked whether the official CFR, instead of being a different substantive document altogether, might not just be a set of guidelines on how the Principles, Definitions and Model Rules of European Private Law could be used on a voluntary basis as an aid to better lawmaking. ${ }^{9}$ The guidelines would, of course, have to refer to a version of the Principles, Definitions and Model Rules fixed as at a certain time, but that would not prevent new guidelines at a later date referring to new versions of the Principles, Definitions and Model Rules as they become available. ${ }^{10}$ Nor would it prevent the guidelines at any time from including "red flags" (warning that certain terms or parts should not be used or should be used only with caution or some modification) or "green flags" (pointing out that although a certain term is used in a precise way in the academic text there is no objection to using it less precisely provided that the context makes the meaning clear).

However it is done, there would be much to be said for trying to avoid any new source of incoherence. We have enough incoherence in European private law.

\section{Some consequences of the tight time schedule}

The time available for the work on the DCFR was very short for a project of this magnitude, although it has to be borne in mind that some of the groups forming part of the network had been working on their own related projects for many years. ${ }^{11}$ The

\footnotetext{
8) Once there is an official CFR it will become confusing to refer to a draft CFR. At that stage it would seem to be preferable to refer to the Principles, Definitions and Model Rules of European Private Law.

9) Cf. the Interinstitutional Agreement of 22 December 1998 on common guidelines for the quality of drafting of Community legislation (OJ C 73, 17.3.1999, p. 1).

10) The question of updating is one which will have to be addressed, but first things first! The guiding principle would presumably be a measure of stability (certainly as regards basic concepts) combined with a measure of flexibility.

${ }^{11)}$ Indeed in so far as the Study Group on a European Civil Code is the successor body to the former Commission on European Contract Law (the Lando Commission) the work has been going on since 1982.
} 
network of researchers set up by the Commission (the Copecl network) was established only in 2005. A large part of the work had to be submitted by the end of 2007 and the rest has to be submitted by the end of December 2008.

For the drafting groups this shortage of time has had three unfortunate consequences. First, it has not been possible in the time available to harmonise the terminology and drafting style of the Principles of European Insurance Law with the rest of the DCFR. Secondly, it has not been possible to take into account the work of the evaluative groups. And thirdly, there will be faults within the DCFR which could have been identified and removed if there had been more time.

The problems were even more acute for some of the other groups in the network. In so far as they were expected to evaluate the DCFR rather than provide background research, analysis or support they were in a difficult position. They could hardly be expected to evaluate a constantly changing text. Some have waited until now, so that their work will only be published in the months to come. The group formed by the Association Henri Capitant and the Société de Législation Comparée (the AHC/ SLC group), which was charged with elaborating a common terminology and a set of guiding principles, solved the problem by concentrating on the Principles of European Contract Law on which the DCFR is partly based. ${ }^{12}$ Fortunately the work on terminology is highly compatible with the work done by the drafting groups and will complement it in a most useful way. Discussions are continuing about how best to incorporate the work on guiding principles. I will come back to that later.

It is probably the stakeholders, however, who suffered most from the tight timescale. Consultation workshops could not be organised in a logical way but had to be geared to what texts were most readily available. Even those texts were not always in final form. It cannot be pretended that the consultation process has been entirely satisfactory.

On the other hand, good work has been done. All groups, including the stakeholders, have been able to make useful contributions. Although the timescale was not ideal, it had the big advantage of forcing the pace. We would not be where we are today without this time pressure. And we are still at the stage of a draft CFR.

\section{The Interim Outline Edition of the DCFR}

Not only are we still at the stage of a draft CFR but even that is not complete. What has been published so far is an interim outline edition of the DCFR. It is interim because further Parts and Books have still to be added and because there is still time for a limited number of corrections and improvements. It is an outline edition because it consists only of the draft Articles. Comments and national notes have been submitted to the Commission but the notes on some of the later Books are still in a raw state and others need to be checked and updated.

The main title is Principles, Definitions and Model Rules of European Private Law. That reflects the wording used by the Commission in its communications. It is easy enough to know what is meant by definitions and model rules but "principles" caused some debate and some difficulty. The Introduction to the Interim Outline Edition contains a list of some general principles which underlie the model rules in the

\footnotetext{
${ }^{12)}$ See Association H. Capitant et Société de législation comparée [1] and [2].
} 
DCFR. These include a commitment to justice, freedom, human rights, economic welfare, solidarity and social responsibility, rationality, legal certainty, predictability and efficiency. Of course, these principles sometimes conflict and the model rules sometimes have to balance one against another. We are still trying to work out the best way of incorporating guiding principles, taking full account of the excellent work done by the AHC/SLC group, ${ }^{13}$ but even when this is done there will remain a rather big underlying question.

If there are so many principles and if they conflict, and if they are not ranked in any order of priority, what is the point of having a statement of them? Frankly, I think a preliminary statement of principles could be omitted without this making any difference to the utility of the model rules and definitions. But such a statement is not pointless. We live in a European society with a plurality of values. The Study Group and the Acquis Group were groups with a plurality of values. A statement of principles could help to make it clear that the model rules are based on a plurality of values. The important point is the negative one: the rules are not based on, say, purely mercantile values or purely paternalistic values. ${ }^{14}$ Like all national systems of private law within the EU they attempt to reflect and balance various values.

\section{Scope of the academic DCFR}

It has already been mentioned that the scope of the academic DCFR is wider than contract law. This should not be surprising, given its origins in PECL and the work of the Study Group on a European Civil Code. It is well known that PECL, although called "Principles of European Contract Law", already went beyond contract law. Nobody would have expected the DCFR to be narrower than PECL in its coverage. And the Study Group had considerably expanded PECL even before the Group became part of the Copecl network.

If the title of PECL was misleadingly narrow, the title of the DCFR is misleadingly wide. It refers to European Private Law but it does not cover the whole of private law. It does not deal with the law of persons, family law or succession law. It does not deal with company law or partnership law, or employment law or the law on negotiable instruments. It does not deal with land law or the law on immovable property generally. ${ }^{15}$ It does, or will, deal with what would traditionally be covered by the law of contracts and obligations plus some aspects of movable property law.

The result is that the DCFR will contain rules on many aspects of private law which might be of interest to the legal advisers of any natural or legal person doing business in Europe. From a functional point of view this coverage is not too wide.

\footnotetext{
13) There was a constructive discussion in Paris on 25 March 2008 between two members of the Compilation and Redaction Team and the two co-ordinators of the AHC/SLC group. The topic was then discussed at some length at a meeting of the Compilation and Redaction Team in Edinburgh at the beginning of April 2008. A small sub-committee of the Compilation and Redaction Team has been given the task of producing a draft for further consideration.

${ }^{14)}$ Not that the two are totally opposed in any event. Soundly based mercantile values would not tolerate abusive practices, which are in nobody's interests. Soundly based paternalistic values would not tolerate excessive protection, which is also in nobody's interests.

${ }^{15)}$ I. $-1: 101$ (Intended field of application) paragraph (2).
} 
But is it too narrow? The fact that it is confined to private law, and indeed to certain aspects of private law, may seem to some to be rather old-fashioned and out of touch with contemporary reality. It is certainly difficult nowadays to preserve a distinction between public and private law for practical purposes, or for theoretical purposes. The legal advisers of a company seeking to engage in activities in Europe would have to consider many aspects of law going well beyond what is in the DCFR, including perhaps tax law, competition law, employment law, intellectual property law, planning law, health and safety regulations and other special regulatory regimes. Those concerned with consumers' rights would have to consider public law rules and remedies and perhaps parts of criminal law. Legal thinkers concerned with issues of social justice or economic efficiency in a whole legal system would have to consider not only classical private law but also tax law, competition law, employment law, social security law, health law, housing law and so on. However, the law has to be packaged somehow and a functional approach based exclusively on divisions such as "All the law a European construction firm needs to know" or "All the law a European seller of goods needs to know" or "All the law a European consumer needs to know" would not be very satisfactory for general purposes. There would be too much repetition, too many gaps and too much law of a transitory nature. It can perhaps be left to legal authors and publishers to supply such accounts. For general civic purposes there are advantages in the rather traditional approach adopted by the DCFR. The important thing is to keep private law in context. It is not the whole of the law which affects people's lives. It is probably not even the most important part of the law which affects people's lives. But the fact that it is now just a small part of the law - that it has diminished in relative importance - does not mean that it is unimportant.

One final thought on scope. It is not fixed in stone. The DCFR is structured in such a way that parts can be added or subtracted as the need arises or the opportunity presents itself.

\section{Structure of the academic DCFR}

To a large extent the structure of the DCFR is straightforward and obvious. The main division is into Books, Parts and Chapters.

Book I is quite short and deals with matters of relevance to the whole of the DCFR intended scope of application, definitions, interpretation and development of the rules. Basically it tells the reader how the DCFR is to be used. Book II deals with contracts and other juridical acts. Book III deals with contractual and non-contractual obligations and corresponding rights. Book IV deals with specific contracts and the rights and obligations arising out of them. It is divided into parts, with a part for sales, a part for lease of goods, a part for services, a part for commercial agency, franchise and distributorship contracts, and so on. This is so that parts can be added later without disturbing the numbering of later Books. Book V deals with benevolent intervention; Book VI with non-contractual liability for damage and Book VII with unjustified enrichment. These are the matters already covered. Book VIII will deal with the ownership and possession of movables; Book IX with proprietary securities and Book X with trusts. 
The main problem was in relation to Books II and III - contracts and obligations. In the end, after several experiments, much discussion and at least two votes, the structure you see in the DCFR was formally and decisively adopted. The key to it is the definition of a contract as a type of agreement. A clear distinction is drawn between a contract in this sense and a contractual relationship resulting from $\mathrm{it}^{16}-\mathrm{a}$ relationship which usually consists of obligations and corresponding rights. Contracts (and other juridical acts) come in Book II and obligations and corresponding rights in Book III. So Book II deals with topics which relate to a contract as a juridical act formation; contracts made by representatives; grounds of invalidity; interpretation; contents and effects; and so on. It includes material on the pre-contractual stage and on rights of withdrawal. Book III deals with topics relating to obligations and corresponding rights - modalities of performance; remedies for non-performance; plurality of debtors and creditors; transfer of rights and obligations; set-off and merger and prescription.

The DCFR therefore avoids two common faults. One is to put obligations under the heading of "Contracts": the other is to put contracts under the heading of "Obligations". Neither is correct. An obligation is not a contract; and a contract is not an obligation. It is important to note that this division between Book II and Book III would still hold even if Book III were confined to contractual obligations and corresponding rights. It is also important to note that the order of treatment of the topics in the DCFR Books I to III is essentially the same as in PECL. It follows a natural chronological sequence. The only difference is that it is not all brought under the heading of "contract law". The Lando Commission itself was well aware that it was inappropriate to use the term "contract law" to cover everything which eventually appeared in PECL, but it had started down a certain path some nineteen years earlier and decided just to proceed. ${ }^{17}$

There was also a problem of structure within Book III. Some people thought that it would be helpful, for the convenience of readers and for presentational reasons, to have separate provisions on contractual and non-contractual rights and obligations. This was a reasonable point of view and strenuous attempts were made to accommodate it. However, all these attempts proved unsatisfactory. In the end it was decided to avoid excessive repetition and cross-referencing, or a weak and unhelpful resort to application by analogy, by framing the rules on obligations and corresponding rights so far as possible in general terms. Where a rule applies only to contractual obligations or rights this is clearly stated.

\section{General relationship to PECL and other instruments}

The DCFR incorporates PECL (with some changes) but it includes very much more and it will be, of course, much more up to date and complete so far as the national notes are concerned. In accordance with the wishes of the Commission it includes

\footnotetext{
16) There may, under the DCFR, be contracts which do not give rise to any continuing contractual relationship, such as a contract to terminate immediately an already existing relationship.

17) See Lando/Clive/Prüm/Zimmermann [4], p. xvi. "In the end it was decided to retain the title Principles of European Contract Law while recognising that some of those principles apply also to non-contractual obligations and are best expressed in general terms."
} 
a great deal of acquis-based material (much of it relating specifically to contracts between businesses and consumers); it includes more definitions; and it tries to be much more precise and coherent in its use of terms and terminology. So the DCFR can be regarded as a revised and updated version of PECL plus a lot of other material.

It is interesting to note that some of the changes mean that, in the areas of common coverage, the DCFR is even closer to the Unidroit Principles than PECL was. ${ }^{18}$ That is a good thing, not only because the Unidroit Principles are well done and successful but also because we live in a globalised environment and, other things being equal, it is better that European model rules should be consistent, rather than inconsistent, with internationally recognised models.

Mention should also be made of the interesting and often innovative preliminary draft European Code of Contract produced by the Academy of European Private Lawyers based in Pavia. ${ }^{19}$ This was not adopted as a basic model by the Study Group on a European Civil Code, for the obvious reason that the Study Group was the successor body to the Lando Commission which had produced PECL, but it is a valuable publication to which reference has been made in the preparation of the DCFR. ${ }^{20}$ Many of the policy choices made in the draft European Code of Contract are similar to those made by PECL and carried forward into the DCFR.

\section{Some differences from PECL}

There is no time to mention all of the changes from PECL but it might be useful to mention some of those which are of a more general nature. I will concentrate on Books I to III.

\subsection{Inclusion of acquis group material in Books II and III}

Books II and III of the DCFR contain substantial blocks of rules derived from material provided by the Research Group on the Existing EC Private Law (the Acquis Group). There are rules on non-discrimination in the provision of goods and services available to the public; ${ }^{21}$ on marketing and pre-contractual duties; ${ }^{22}$ and on the right of withdrawal from certain contracts within a short "cooling-off" period. ${ }^{23}$ There are more extensive rules on unfair contract terms. ${ }^{24}$

One of the challenges in producing the DCFR was to merge the "classical" contract law approach of PECL with the newer, more overtly policy-based, approach of

\footnotetext{
18) This can be seen in, for example, the rules on representation; stipulations in favour of third parties; cure by a non-performing debtor; and assignment of rights to performance.

${ }^{19)}$ The official version is the French one - L'avant projet de code européen des contrats. An English translation by Coggan, Gandolfi and Stein is printed in Fundamental Texts on European Private Law. A new and substantially revised English translation by Professor Harvey McGregor QC is published in a special issue of the Edinburgh Law Review for 2004.

${ }^{20)}$ It is frequently referred to and taken fully into account in the work of the AHC/SLC group referred to in note 12 .

${ }^{21)}$ II. $-2: 101$ to II. $-2: 105$ and III. $-1: 105$.

22) II. $-3: 101$ to II. $-3: 201$ (the rules in II. $-3: 301$ to II. $-3: 401$ had their equivalent in PECL).

23) II. $-5: 101$ to II. $-5: 202$.

24) II.-9:401 to II.-9:401. Some of these rules, but not all, had equivalents in PECL.
} 
the acquis. Adjustments were necessary in both directions. For example, the Acquis Group's approach to "writing" and "signature" (designed to cater for the electronic age) has been adopted throughout the DCFR. ${ }^{25}$ The same applies to the Acquis Group's use of "business" and "consumer". ${ }^{26}$ In the other direction, some of the Acquis Group's texts had to be slightly changed to fit into the DCFR. Whether the merger has been successful is for others to judge, but significant progress has undoubtedly been made and there is no reason to suppose that any remaining problems could not be quickly solved.

\subsection{Other new material in Books II and III}

There is new material on the computation of time in the DCFR. PECL had only a limited provision on the computation of time. It applied only to the computation of time in relation to "a period of time set by a party in a written document for the addressee to reply or take other action". ${ }^{27}$ The lack of more general rules was noted and regretted during the preparation of the Chapter on Prescription. The DCFR now has more comprehensive provisions ${ }^{28}$ which draw on existing European law. ${ }^{29}$

There is a new rule on mixed contracts in the DCFR. ${ }^{30}$ The need for this became obvious as work proceeded on the special contracts in Book IV. Many contracts are a mixture of sale and services, or a mixture of different kinds of services. Other kinds of mixes are also common. It is useful to have some indication of how the different rules are to apply in such cases.

There is a new rule on the effect of failure to notify a non-conformity in goods or services supplied to a person who is not a consumer. ${ }^{31}$ The reason for the inclusion of this rule in Book III was to generalise a rule which was appearing in unnecessarily different forms in different Parts of Book IV.

There are new rules on unilateral juridical acts ${ }^{32}$ a matter which was dealt with only by analogy in PECL. There are also new rules on time-limited rights and obligations; ${ }^{33}$ on the variation and termination of rights, obligations or contractual relationships by agreement ${ }^{34}$ or by notice; ${ }^{35}$ and on the extinction of obligations by performance or merger. ${ }^{36}$ There is a new rule on when, in a case of a plurality of credi-

\footnotetext{
25) For definitions see I.-105 and I.-1:106.

26) Currently defined in the Annex, but the Compilation and Redaction Team has recommended bringing the definitions, because of their importance, into Book I.

27) Art. 1:304.

${ }^{28)}$ See Annex 2. The Compilation and Redaction Team has now recommended bringing these rules into Book I.

29) The rules in Annex 2 reflect rules which are commonly found in national systems and which have been found to be commercially convenient. The actual wording is derived, with minor drafting changes, from the EEC/Euratom Regulation No 1182/71 of the Council of 3 June 1971 determining the rules applicable to periods, dates and time limits.

30) II. $-1: 108$.

31) III.-3:107.

${ }^{32)}$ II. $-4: 301$ to II. $-4: 303$ (Formation) and II.-8:201 to II.-8:202 (Interpretation).

${ }^{33)}$ III. $-1: 107$.

34) III.-1:108.

35) III.-1:109.

36) III.-2:114 and III.-6:201.
} 
tors, different types of right arise. ${ }^{37}$ These rules are not inconsistent with anything in PECL and their content will not, it is hoped, be surprising. The reason for their inclusion is simply to fill gaps.

The Compilation and Redaction Team, following a suggestion by the AHC/SLC group, ${ }^{38}$ will recommend the inclusion of a new Article on the tacit prolongation of a contractual relationship in certain cases where both parties continue to perform the contractual obligations after the expiry of a fixed duration for the relationship. At present there are specific rules in two places in Book IV but nothing in other places where a rule might be expected. It is thought that it would be useful to have a general rule in the first Chapter of Book III.

\subsection{Expanded (or slightly different) treatment of some topics}

The rules on assignment have been expanded in some respects and changed in others. There is a new rule on the basic requirements for an assignment of a right to performance. ${ }^{39}$ PECL had said that certain things were not required but had not said what was required. Related to this is a new rule on right or authority to assign. ${ }^{40}$ There is also a new rule on the most important effect of the assignment of a right to performance - namely that the assignor ceases to be, and the assignee becomes, the creditor. ${ }^{41}$ These additions to the assignment chapter were prompted to some extent by the discussions on the transfer of ownership of movables and by a desire for a greater consistency of treatment. The rules on the effect of a non-contractual prohibition on assignment have also been changed - again partly in order to be coherent with the rules on the transfer of ownership in corporeal movables. The basic rule now is that a contractual prohibition on assignment does not affect the transferability of the right. However, this is qualified by some rules for the protection of the debtor and these rules are in turn qualified so as to facilitate the factoring of debts. The Compilation and Redaction Team will recommend some further changes to the assignment Chapter designed to bring it even more closely into line with the new provisions on transfer of movables. This Chapter has proved to be one of the most difficult ones on which to achieve consensus. This is probably due partly to the nature of the subject-matter and partly to the fact that international instruments on which the text has drawn do not always fit well with some basic concepts of European private law.

The rules on the effect of a stipulation in favour of a third party ${ }^{42}$ are considerably more developed than the equivalent rules in PECL. ${ }^{43}$ This reflects changes in national laws and further thinking since the PECL rules were formulated. ${ }^{44}$ The rules on cure of non-performance by the debtor in an obligation are also expanded. ${ }^{45}$ This took

\footnotetext{
37) III.-4:203.

${ }^{38)}$ Association H. Capitant et Société de législation comparée [1], pp. 519-520 (tacite reconduction).

39) III.-5:104.

40) III. $-5: 111$.

41) III. $-5: 113$.

42) II.-9:301 to II.-9:303.

43) Art. 6:110.

44) See e.g. the English Contracts (Rights of Third Parties) Act 1999.

${ }^{45)}$ III.-3:202 to III.-3:204. Cf. Art. 8:104 of PECL.
} 
account of work done for the Part of Book IV on sales of goods, which itself took account of existing EU law. It was found useful and appropriate to generalise the sales rules and to put them in Book III.

There has been some expansion of the rules on the restitution of benefits after the termination of a contractual relationship on the ground of fundamental non-performance. ${ }^{46}$ Here the work on unjustified enrichment had shown that a number of questions had been left unregulated by the PECL provisions.

The main rule on the duty of good faith has been clarified. PECL had a rule, under the heading of "General Duties" to the effect that:

(1) Each party must act in accordance with good faith and fair dealing.

(2) The parties may not exclude or limit this duty. ${ }^{47}$

That was admirably short but gave rise to a number of questions. Who owed the duty? Was it only a party to a contract, or a party to any transaction or relationship? In what circumstances was the duty owed ${ }^{48}$ What were the sanctions for its breach? ${ }^{49}$ The equivalent provision in the DCFR is clearer in all these respects. ${ }^{50}$ It provides as follows.

(1) A person has a duty to act in accordance with good faith and fair dealing in performing an obligation, in exercising a right to performance, in pursuing or defending a remedy for non-performance, or in exercising a right to terminate an obligation or contractual relationship.

(2) The duty may not be excluded or limited by contract.

(3) Breach of the duty does not give rise directly to the remedies for non-performance of an obligation but may preclude the person in breach from exercising or relying on a right, remedy or defence which that person would otherwise have.

Whether this provision is wider or narrower than the equivalent PECL provision depends on how the PECL provision is interpreted. The DCFR provision may well be wider in one respect (application to non-contractual obligations and rights) but narrower in another (available remedies). At least it focuses the issues more clearly and provides a firmer basis for further debate. Of course this provision must be read along with a number of other provisions referring to good faith and fair dealing in particular contexts. For example, good faith and fair dealing are relevant in the interpretation of the model rules and in the interpretation of a contract. ${ }^{51}$ And there is in the DCFR a duty on any person engaged in negotiating a contract to negotiate in accordance with good faith and fair dealing. ${ }^{52}$

\subsection{Relocation or re-arrangement of some provisions}

The PECL articles on conditions have been relocated. Their curious placing towards the end of PECL was due only to the fact that PECL was produced in parts over a

\footnotetext{
46) III.-3:511 to III.-3:515. Cf. Arts. 9:307 and 9:308 of PECL.

47) Art. 1:201.

${ }^{48)}$ Only in performing a contractual obligation or exercising a contractual right - or what?

49) Were they the same as the remedies for non-performance of an obligation? If so, why was it not called an obligation of good faith? Were they different? If so, in what way?

50) III. $-1: 103$.

51) I. $-1: 102(3)(\mathrm{b})$.

${ }^{52)}$ II.-3:301 (2). Such a duty was implicit in PECL Art. 2:301 also but was not expressly imposed.
} 
long period of time. It was always intended that they should eventually be inserted at a more appropriate place. ${ }^{53}$ As the focus of these articles on conditions is on conditional rights and obligations they appear in the DCFR in Chapter 1 of Book III which contains some general rules on obligations and corresponding rights. They describe particular types of obligations and rights and appear along with rules on time-limited obligations and rights. Within the scheme of the DCFR it would not seem to be correct to put them in the Chapter on the modalities of performance of obligations (place of performance; time of performance; and so on). A conditional obligation may never be performed.

The PECL provisions on Illegality have been incorporated into Chapter 7 of Book II on Grounds of Invalidity. Again its placing in PECL was due only to the fact that it was written long after the other provisions on invalidity. ${ }^{54}$ There is a separate Section in the Chapter on Grounds of Invalidity to deal with vitiated consent or intention. ${ }^{55}$

There is a single Chapter on the Transfer of Rights and Obligations, divided into Sections, instead of two separate Chapters. ${ }^{56}$

And the provision on the duty to negotiate in good faith is now included in a new and expanded Chapter on marketing and pre-contractual duties. ${ }^{57}$

A rather difficult question was the location of the hardship provision - that is to say the provision enabling a court, in exceptional circumstances to vary contract terms or even terminate a contractual relationship because the obligations of one party had become excessively and unforeseeably onerous. ${ }^{58}$ As the essence of this provision is the variation or termination of contractual rights or obligations it is included in Chapter I of Book III along with similar provisions applying to rights and obligations in general. One alternative location might have been the Chapter on performance of obligations, but the essence of the provision has little to do with modalities of performance. Another possible location might have been the Chapter on the contents and effects of a contract, but that Chapter has more to do with the initial contents and effects than with subsequent changes.

\subsection{More precise terminology}

In accordance with the Commission's requirements every attempt has been made to develop a clear and precise terminology and to use it in a coherent and consistent way. There will no doubt still be shortcomings and I hope that people will draw them to the attention of the Compilation and Redaction Group so that they can be corrected. Some of the changes to PECL are therefore designed to express rules hav-

\footnotetext{
53) See Lando/Clive/Prüm/Zimmermann [4], p. xvi.

54) Ibid.

${ }^{55)}$ These changes are similar, so far as they go, to changes recommended independently by the AHC/SLC group. See Association H. Capitant et Société de législation comparée [2], pp. 330 and 452.

56) Also a solution very similar to that recommended independently by the AHC/SLC group. See Fauvarque-Cosson [1], pp. 757-758.

57) Also a solution similar to that suggested by the AHC/SLC group. See Association H. Capitant et Société de législation comparée [1], pp. 215-217 and 264.

58) Professor Bonell [3], fn. 28 criticises the location in the DCFR. However, for the reasons given in the text, that location seems preferable to the location in the UNIDROIT Principles under the heading of "Performance".
} 
ing exactly the same function in more precise words. It is interesting to note that the changes in terminology are often along very much the same lines as recommended independently in the AHC/SLC group's work on this subject. ${ }^{59}$

There is no time to mention all the changes which could be mentioned under this heading. I will just mention a few by way of example.

\subsubsection{Contract/contractual relationship}

PECL uses the word "contract" in different ways. Usually it refers to a type of agreement - a bilateral or multilateral juridical act. Sometimes it refers to a continuing relationship resulting from such an act. It may even refer to a contract document. This can be confusing. The Study Group, after considering the prevailing usage in EU Directives and European and international instruments, including soft-law instruments like PECL itself, decided to use "contract" for a type of bilateral or multilateral juridical act and to use the term "contractual relationship" for the continuing legal relationship which often results from a contract. So a contract is defined as:

... an agreement which gives rise to, or is intended to give rise to, a binding legal relationship or which has, or is intended to have, some other legal effect.

It is a bilateral or multilateral juridical act. ${ }^{60}$

The distinction between a contract and a contractual relationship turned out to be a considerable aid to clarity of thinking in relation to such topics as third party rights and termination for fundamental non-performance. For example, it is obviously not a contract as a juridical act which is terminated. It is a continuing contractual relationship which is terminated. This is not just a pedantic question of accurate usage. It affects the question of how termination is seen. Termination of a continuing contractual relationship would not necessarily be expected to have retrospective effects, although it might be expected that some rebalancing adjustments would be necessary. Termination of a contract as a juridical act might well be expected to have retroactive effects. Of course, people in real life will continue to refer to termination of a contract. That causes no problem The context will make the meaning clear. But for the purposes of legislative drafting there are advantages in precision.

\subsubsection{Duty/obligation}

PECL does not distinguish clearly between "duty" and "obligation". This causes difficulty in relation to those few provisions which use duty rather than obligation,

\footnotetext{
${ }^{59)}$ Association H. Capitant et Société de législation comparée [2]. This Book contains valuable analyses of the notions of Contrat; Obligation/Devoir; Acte juridique/fait juridique; Règles impératives et ordre public, Bonne foi; Préjudice; Dommages et intérêts and Aneantissement (nullité, caducité, inexistence, résolution, résiliation, inefficacité, clause réputée non écrite). Most of these terms, or their equivalents in English, have been the subject of efforts at precision in the DCFR.

${ }^{60)}$ II. $-1: 101$ (1).
} 
including the provision on good faith. ${ }^{61}$ The DCFR distinguishes between a duty and an obligation. ${ }^{62} \mathrm{~A}$ duty is rather more vague and rather more general. It need not involve a specific creditor. One can, for example, have a duty to be a good citizen or not to harm other people in certain ways. A duty need not have a legal sanction. So any provision imposing a duty should state clearly the effects of a breach (as the provision on good faith in the DCFR now does). Under the DCFR an obligation is defined as:

... a duty to perform which one part to a legal relationship, the debtor, owes to another party, the creditor. ${ }^{63}$

The creditor will have a corresponding right to performance. Unless otherwise stated, a non-performance of the obligation will bring into play the remedies for non-performance set out in the DCFR. It follows that, under the scheme of the DCFR, all obligations are duties but not all duties are obligations.

Another question in relation to the word "obligation" is whether an obligation is a bilateral relationship or a unilateral duty owed by the debtor. The former usage seeing the obligation as a tie or vinculum - has a long and respectable history but the latter usage is now more prevalent and it is the latter usage which was expressly adopted by the Study Group at its Warsaw meeting. The debtor has an obligation and the creditor has a corresponding right. The obligation in DCFR usage is not the whole relationship but the debtor's part of the relationship.

\subsubsection{Assignment/act of assignment}

PECL used "assignment" sometimes of the contract or other juridical act which is intended to effect a transfer of a right to performance ${ }^{64}$ and sometimes of the actual transfer itself. ${ }^{65}$ This led to some confusion. The DCFR distinguishes between the two. It uses "assignment" for the actual transfer and "act of assignment" for the contract or other juridical act which is intended to effect the transfer.

\subsubsection{Performance/benefit received by performance}

PECL sometimes used "performance" of the act of performing an obligation and sometimes of the benefit received by the performance. ${ }^{66}$ The two are quite different. An act of performance, once done, does not, for example, have a market value. Car dealers sell cars, not the acts by which those who sold the cars to them performed their contractual obligations. The DCFR tries to reserve "performance" for the act of performing and to refer to the benefits received by performance where this is what is meant.

\footnotetext{
61) PECL Art. 1:201.

${ }^{62)}$ See III.-1:101 (1) and Annex 1.

63) III.-1:101 (1).

${ }^{64)}$ See e.g. PECL Art. 11:104 (Form of assignment).

${ }^{65)}$ See e. g. PECL Art. 11:201 (Rights transferred to assignee).

${ }^{66)}$ See e.g. PECL Art. 9:401(1) (Right to reduce price).
} 


\subsubsection{Void/voidable/invalid/ineffective}

The meaning of these words was not always clear in PECL. Indeed, these and similar terms or their equivalents are very often unclear in national systems. ${ }^{67}$ They are quite important and quite useful. The DCFR attempts to clarify them. ${ }^{68}$

\subsection{Other drafting changes}

PECL was very well drafted. In many respects the DCFR follows its approach and style. For example, both instruments avoid the drafter's "shall", which is at variance with ordinary language and is quite unnecessary. ${ }^{69}$ And both use gender neutral drafting. ${ }^{70}$ However, the close scrutiny which PECL received in the course of the work of the Study Group revealed various small ways in which the drafting could be improved. Again, I will give just a few examples.

\subsubsection{Use of juridical act}

PECL does not use the expression "juridical act". Instead it refers to "statements and conduct indicating intention". ${ }^{71}$ That, however, is too wide. "I am going out to buy a newspaper" is a statement indicating intention. Lifting a soup spoon and moving it in the direction of a plate of soup is conduct indicating intention. Neither needs to be regulated by rules on grounds of invalidity, interpretation and so on. The DCFR defines a "juridical act" - actually one of the key building blocks of a system of private law, along with legal relationships, obligations and rights - as:

any statement or agreement or declaration of intention, whether express or implied from conduct, which has or is intended to have legal effect as such. It may be unilateral, bilateral or multilateral. ${ }^{72}$

\subsubsection{Use of debtor/creditor}

Often, but not always, ${ }^{73}$ in dealing with the non-performance of an obligation, the English text of PECL used the term "aggrieved party" to describe the creditor and the term "non-performing party" to describe the debtor. The French text generally used "créancier" and "débiteur". ${ }^{74}$ There is nothing wrong with describing parties to a legal

\footnotetext{
67) See Association H. Capitant et Société de législation comparée [2], pp. 446-491.

${ }^{68)}$ See Annex 1.

${ }^{69)}$ This is one of the few respects in which the DCFR differs from the recommendations in the Joint Practical Guide for the drafting of Community legislation. It does so quite deliberately because the use of the drafter's "shall" in EU legislation is contrary to the principle (see Joint Practical Guide paragraph 1.4.1) of using everyday language so far as possible.

${ }^{70)}$ The DCFR also tries so far as possible to avoid using "it" to cover men, women and legal entities.

${ }^{71)}$ Art. 1:107. Principles apply with appropriate modifications to "unilateral promises and to other statements and conduct indicating intention". See also Art. 1:303(6) "In this Article, 'notice' includes the communication of a promise, statement, offer, acceptance, demand, request or other declaration".

72) See II.-1:101(2) and Annex 1.

73) Contrast, for example, Art. 9:101 (“creditor") with Art. 9:102 (“aggrieved party”).

74) See e.g. Art. 9:504.
} 
relationship as "aggrieved" (if they are actually aggrieved) or "non-performing" (if it is made clear what it is that they are not performing $)^{75}$ but it is unnecessary if the terms "creditor" and "debtor" are already available. It infringes against the drafting principle of not multiplying terms unnecessarily. The DCFR uses "creditor" and "debtor" in these situations. Another possibility would have been "obligee" and "obligor"76 but this had already been rejected by the Lando Commission on the grounds that it was confusing. ${ }^{77}$ It is also contrary to ordinary usage: people in the streets in Englishspeaking countries do not go about talking of obligors and obligees.

\subsubsection{Use of ,, could reasonably be expected to know”}

A problem arises when a provision needs to refer to the situation where a person did not actually know something but could reasonably be expected to have known it. How should that be expressed? Sometimes PECL used "ought to have known"78 and occasionally "could not have been unaware". ${ }^{79}$ The "ought" formula implies that there is a duty to know, which will not usually be the case. ${ }^{80}$ The "knew or could not have been unaware" formula, although it now has a long pedigree, is not a very happy one. "Could not have been unaware" means "must have been aware". A person who must have been aware of something was aware of it. So, logically, the formula says "knew or was aware" which just means "knew or knew". The DCFR generally uses "knows or could reasonably be expected to know" or some variant of that formula (depending on the appropriate tense).

\subsubsection{Performance of obligation (not contract)}

PECL sometimes referred to "performance of a contract". ${ }^{81}$ However, a contract is not performed - and this is true whether the word is used to refer to a juridical act or to a relationship. What is performed is an obligation which arises from the contract and which is part of the legal relationship between the parties.

\subsubsection{Time expressions}

Provisions often require something to be done at a certain time or within a certain broadly described period of time, for example "immediately"; or "promptly"; or "without delay"; or "without undue delay"; or "without unreasonable delay"; or "within a reasonable time". The DCFR attempts to standardise such expressions. In the absence of some special reason requiring a different formula it uses three expressions - "immediately"; "without undue delay" and "within a reasonable time".

\footnotetext{
75) See above.

76) As in the Unidroit Principles of International Commercial Contracts.

77) The story is told of one meeting where half the contributors to a surprisingly difficult discussion on a simple matter were using "obligee" to refer to the creditor and the other half were using it to refer to the debtor.

${ }^{78)}$ See e.g. Art. 4:111(2).

${ }^{79)}$ See e. g. Art. 3:205(3)(a).

${ }^{80)}$ Sometimes, however, this will be the case and then there is no objection to the "ought" formula.

${ }^{81)}$ See Arts. 6:111(2); 8:107; 9:302; 9:502.
} 


\section{Criteria for assessment of academic DCFR}

\subsection{As a toolbox ${ }^{82}$}

From the point of view of a toolbox of terms and concepts for better lawmaking the main question would seem to be whether the concepts and terminology used in the DCFR, and the definitions of terms, are suitable for the purpose for which they are intended. From the toolbox point of view coverage is also important. The more tools in the box the better, even if some of them might not be used immediately. However, from the toolbox point of view the content of the model rules is probably not so important. The rules could be seen as a sort of theoretical demonstration that the terms and concepts can be used in a consistent and coherent way. It is true that the drafting groups tried very hard to arrive at fair and acceptable model rules in the DCFR but this was because it was always envisaged that the academic DCFR would have functions going beyond that of a toolbox of terms and concepts.

\subsection{As a possible basis for an optional instrument}

From the point of view of the DCFR as a possible basis for an optional instrument that is, a set of rules which parties to a contract could choose as the rules of law governing their relationship ${ }^{83}$ - the usefulness of the terms and concepts is again important, but indirectly. It would be useful for a European optional instrument to fit the terminology used in the rest of European private law.

Coverage is also important from this point of view and again it is arguable that a wide coverage would be useful. The fewer gaps there are the better. Of course, the parties to a contract could not, by opting to have their contract governed by a set of rules, subject third parties directly to those rules. This might appear to set some quite strict limits to the possible coverage of an optional instrument. However, it should not be assumed that the rules of an optional instrument should therefore be confined to two-party situations. There could be a multi-party opt-in. For example, all the parties to a big European construction project could opt in, with the effect that, within the group, rules on such matters as plurality of debtors and creditors, or assignment of rights to performance, or transfer of an entire contractual position could have a useful role to play. All in all, it seems better that solutions to fringe problems should be compatible with solutions to the primary problems. Even with a wide coverage, it would be necessary to have a national system to fill remaining gaps. The parties could provide for example that their contract and contractual relationship should be

\footnotetext{
82) The Council's statement of 18 April 2008 uses the expression a "tool for better lawmaking" but I prefer "toolbox" (the assumption being that it is full, not empty) for present purposes because it conveys the impression of a set of different tools for different purposes, organised with convenience and accessibility in mind. A single tool would have to be something like a Swiss army knife.

${ }^{83)}$ What is envisaged here is a set of rules which could be chosen by a choice of law clause in a contract, in the same way as a State system of laws could be. This must be distinguished from the simple incorporation of terms into a contract (the whole still being governed by a State system of law). It is always open to parties to incorporate terms drawn from any source into their contract if they choose. For this purpose the academic DCFR is already available. It is also open to States to adopt rules from any source as a basis for their own legislation. For this purpose too the academic DCFR is already available.
} 
governed by the optional instrument supplemented where necessary by the law of country X.

It is clear, too, that from the point of view of an optional instrument the content of the model rules would be important. There is a problem here with regard to mandatory rules, such as many consumer protection rules. Clearly an optional instrument should not become an easy way out of such protective rules. The best solution would probably be to provide that in opting for the instrument the parties could not exclude the application of those of its rules designated as mandatory. A purported opting-in which excluded the application of such rules would be regarded as ineffective, so that the normal choice of law rules would apply. This raises the question whether there might be a case for two optional instruments - one for contracts between businesses containing very few mandatory rules, and another for contracts between businesses and consumers, containing more mandatory rules. This is not strictly necessary, of course, as rules for consumer contracts would automatically disapply themselves in the case of contracts between businesses. It would be just a question of presentation. I am not recommending this solution - just mentioning it as a possibility.

One of the perennial questions in relation to any set of legal rules is the balance between certainty and flexibility. Should an optional instrument err on the one side or the other? It seems clear that it should err on the side of flexibility. It has to cater for a wide variety of contracts. Any fixed rules would be likely to be inappropriate in relation to many such contracts. For example, fixed time limits or fixed penalty clauses would be quite likely to be unsuitable for many contracts. It is safer to have default provisions of a general type, using such vague criteria as reasonableness and good faith and fair dealing, which would not surprise the parties and would never be totally unsuitable, than to have specific rules which might surprise the parties and prove unsuitable for their situation. Parties who wish to have precise rules for their particular situation can always agree on them (subject to any mandatory rules applicable). This question of certainty versus flexibility is a question of balance. There is one sure way of finding out if the balance is right and that is to see if people opt for the instrument. If they do not, then some adjustment one way or the other would be required.

\subsection{Other purposes}

For all other purposes all of the aspects identified so far would seem to be important - suitability of terms and concepts, wide coverage, and content of model rules. Of course, content would generally be important only as a starting point. If some of the model rules were, for example, used as the basis for specific legislative proposals, the legislator would provide the final product.

\section{Conclusion}

There is one important question at this stage. Can we move forward on the basis of the DCFR? To speak plainly, I think it would be stupid not to. The DCFR exists. It has been formulated and agreed by leading private lawyers from all over Europe. It attempts to take into account the comments of stakeholders in so far as they were available. It attempts to meet the Commission's formal requirements. It certainly 
comes closer, by several years' work, to doing so than any other existing instrument. It will have faults. That is inevitable. It will give rise to differences of opinion on issues such as the balance between certainty and flexibility. That is also inevitable. But, with the help of academic commentators and stakeholders and expert officials, faults can be identified and corrected.

The work on the preparation of the DCFR has taken place in an atmosphere of cooperation and good will. It is to be hoped that that spirit will continue to prevail as we move forward. And so, I introduce the academic DCFR, not as a finished product not as a perfect product - but as a small step along the way to a stronger and better European private law.

\section{References}

Association H. Capitant et Société de législation comparée: Principes Contractuels Communs, coll. Droit privé comparé et européen, volume 7 (2008)

Association H. Capitant et Société de législation comparée: Terminologie Contractuelle Commune, coll. Droit privé comparé et européen, volume 6 (2008)

Bonell, M. J.: The CISG, European Contract Law and the Development of a World Contract Law. Am J Comp L 56, pp. 1-28 (2008)

Lando, O., Clive, E., Prüm, A. and Zimmermann, R. (eds.): Principles of European Contract Law: Part III, Kluwer Law International (2003) 